\title{
The relationship between self-efficacy and accounting students' academic performance at a South African university
}

\section{Riley Carpenter, Sihaam Shamsoodien}

College of Accounting, University of Cape Town, South Africa.

\begin{abstract}
Racial transformation is crucial for South African higher education institutions, the accounting profession and the country as a whole. Consequently, determinants of students' academic success must be at the forefront of accounting education research. Understanding these determinants will assist universities to better assist students with their learning. This study focused on self-efficacy in academic performance - a previously limited research area in South African accounting education. The aim was to determine the relationship between self-efficacy and academic performance amongst students registered in a second-year undergraduate course for an accounting degree at a South African university. It was found that self-efficacy was moderately positively correlated with academic performance. The findings indicate that it is worthwhile performing further empirical research on self-efficacy, especially while controlling for other significant factors affecting students' academic performance.
\end{abstract}

Keywords: Self-efficacy; academic performance; accounting; South Africa; student; success. 


\section{Introduction}

South African higher education institutions have made significant progress with regards to transformation in recent years, including increased access, particularly for Black South Africans. However, this has not translated into equitable graduation rates. The accounting profession needs these students to succeed academically and start contributing to the economic stability of the country, thereby promoting equality and rectifying the injustices of the past.

Therefore, it is paramount to understand the factors affecting students' academic success to identify who needs the support, how best to offer it and when to do so. While prior accounting education research in South Africa has focused on demographic and academic factors affecting academic performance, there are other potential determinants of success identified in the literature of other disciplines as well as internationally. One of these determinants is selfefficacy.

The present research is motivated by two studies. Joynt and de Villiers (2019) found an association between self-efficacy and academic performance, while Shamsoodien and Carpenter (2020) identified the need to investigate the impact of self-efficacy on student academic performance while controlling for determinants of success.

Using Kendall's tau-b correlation coefficient, this study determined the relationship between self-efficacy and academic performance in students registered for a second-year undergraduate course in an accounting degree at a South African university.

\section{Literature Review}

Recent accounting education research has focused on factors affecting either academic performance or degree completion. However, this narrow approach of measuring student outcomes has led to an expansion of the explanatory variables, which now include students' personal development and integration into an institution's environment such as locus of control, student engagement, self-efficacy or institutional culture. It is paramount to first identify determinants of academic success before developing targeted interventions to improve graduation rates.

\subsection{Biggs 3P Model}

There are multiple factors affecting students' academic success in higher education institutions. The Biggs 3P model explains the three stages of student learning and the factors that could affect students' academic performance (Biggs, 1987). First, the presage stage includes personal factors (e.g. intelligence, background or demographics) and situational factors (e.g. subject content or course structure). Second, the process stage relates to the way in which the student goes about learning. Third, the product stage relates to student performance and 
includes either cognitive factors (high-level informational or detail-oriented structures) or affective factors (how the student experiences learning) (Biggs, 1987).

The model has been used extensively in many fields, including accounting education (Davidson, 2002; Papageorgiou, 2017). While Biggs (1987) focused on students' learning approaches, it was acknowledged that presage factors assisted in developing the learning approach. Therefore, factors such as prior academic results, age, gender, race, language and potentially self-efficacy, determine students' learning approach, which subsequently affects their academic performance.

\subsection{Academic and demographic factors affecting determinants of success}

The single best predictor of academic performance at all levels for accounting students in South Africa is academic performance in the immediately preceding year of study, whether in undergraduate studies (Jansen \& De Villiers, 2016; Papageorgiou \& Halabi, 2014; Swart \& Becker, 2014), postgraduate courses (Pullen et al., 2015; Steenkamp, 2014; Swart \& Becker, 2014) or professional exams (van Wyk, 2011). This is likely due to the hierarchical knowledge structure of accounting studies (Myers, 2017).

Numerous South African studies report that students who took accounting as a subject in Grade 12 outperformed those who did not (Bokana \& Tewari, 2014; Papageorgiou, 2017; Papageorgiou \& Carpenter, 2019). However, any advantage gained is not sustained beyond the first year of undergraduate study (Jansen \& De Villiers, 2016; Papageorgiou \& Halabi, 2014). Overall, performance in Grade 12 is strongly correlated with academic success at all levels of tertiary education (Bokana \& Tewari, 2014; Jansen \& De Villiers, 2016; Pullen et al., 2015).

South African literature largely concludes that younger students outperform older students, whether at the undergraduate level (Bokana \& Tewari, 2014; Jansen \& De Villiers, 2016), postgraduate level (Steenkamp, 2014; Ungerer et al., 2013) or in professional exams (Roos, 2009; van Wyk, 2011). However, there is some research indicating the contrary, especially at the start of an undergraduate degree (Papageorgiou, 2017).

Due to contradictory findings in South Africa, there is inconclusive evidence on the impact of gender on accounting academic performance. Some studies indicate outperformance by males in undergraduate studies (Jansen \& De Villiers, 2016), while others report females outperforming males in both undergraduate studies (Carpenter \& Kunaka, 2018; Coetzee et al., 2016) and professional exams (Roos, 2009). Yet other studies have found no correlation between gender and academic performance in undergraduate studies (Bokana \& Tewari, 2014; Papageorgiou, 2017; Papageorgiou \& Halabi, 2014; Steenkamp, 2014) or in professional exams (van Wyk, 2011).

South Africa has a history of institutionalised racial disparities in education and therefore it is to be expected that there would be significant differences between the academic performance 
of White students and that of other racial groups (Bokana \& Tewari, 2014; Papageorgiou, 2017; Sartorius \& Sartorius, 2013; Ungerer et al., 2013). The literature is clear that White students outperform all other race groups, Black students are less likely to pass and Black African students fare the most poorly. While access to tertiary education and funding has widened, student attrition rates remain high, and will likely only change substantially once deficiencies in the secondary schooling system are addressed, and there are employment opportunities for graduates (Kaburise, 2014). Graduation rates and time-to-completion are also affected by funding and financial aid (Carpenter \& Roos, 2020).

The impact of race on academic performance is linked to home language and the language of instruction. South Africa has 11 official languages; however, only two of them-English and Afrikaans - are offered as the language of instruction in tertiary institutions. The literature notes a strong positive correlation between academic success and assessment in one's first language (Bokana \& Tewari, 2014; Papageorgiou, 2017; Steenkamp, 2014; Swart \& Becker, 2014; Ungerer et al., 2013; van Wyk, 2011). In contrast, other research suggests that Grade 12 language marks are not correlated with academic success at university (Aboo, 2017; Jansen \& de Villiers, 2016; van Rooy \& Coetzee-van Rooy, 2015) and that multilinguism may contribute to academic success (Martirosyan et al., 2015; Papageorgiou, 2017).

\subsection{Self-efficacy as a factor affecting determinants of success}

Perceived self-efficacy is a person's belief in their capabilities to produce designated levels of performance. In academic performance literature, self-efficacy relates to the belief that one will achieve good marks in a particular subject. Most literature confirms that self-efficacy is positively correlated with academic performance. That said, there is limited research on selfefficacy in the field of accounting higher education in South Africa, and therefore international literature should first be investigated.

International studies on accounting students provide contradictory results. Some find evidence of an inverse relationship between pessimism and academic performance (Christensen et al., 2002; Mooi, 2006). However, there seems to be more literature indicating a positive relationship between self-efficacy and academic performance (Beatson et al., 2020; Byrne et al., 2014; Gul \& Fong, 1993). In particular, Beatson et al. (2020) note that self-efficacy trumps high school experience as the most powerful predictor of academic success.

In a South Africa, Joynt and de Villiers (2019) investigated the impact of a preparatory course on students' academic performance in a first-year Accounting course. They report a positive association between academic performance and self-efficacy. However, as there is scant research on this topic in South Africa, it is uncertain whether this finding is pervasive or whether the impact of self-efficacy on academic performance follows the contradictory international evidence in this field. 
Therefore, it is worthwhile first exploring if there is a relationship between self-efficacy and academic performance in accounting studies in South Africa, and thereafter to investigate the extent and depth of that relationship.

\section{Method}

The objective of this study was to identify whether a relationship exists between self-efficacy and accounting students' academic performance. The students investigated were registered for Corporate Governance I, a second-year undergraduate course in an accounting degree at a South African university.

Self-efficacy was assessed by measuring students' responses to the survey statement, "I feel confident in my ability to achieve a grade that is above average" (McKenzie \& Schweitzer, 2001) and responses were rated using a five-point Likert scale ranging from $1=$ not confident at all to $5=$ completely confident. Ethical clearance was obtained prior to the survey distribution. The use of a single statement to measure participants' self-efficacy is consistent with prior literature (McKenzie \& Schweitzer, 2001). Academic performance was verified through students' final marks in the course, obtained from institutional student records.

The final number of students who completed the survey and for whom a full set of records was available amounted to 401, yielding an overall response rate of $70 \%$. From a comparison of the sample to the population, there was representation and consequently, non-response bias was not expected (Nishimura et al., 2016).

The data comprised the ordinal variable related to self-efficacy and the continuous variable related to final marks. Therefore, a Kendall's tau-b $\left(\tau_{\mathrm{b}}\right)$ correlation coefficient-a nonparametric measure of the strength and direction of association between self-efficacy and final marks_-was calculated using IBM SPSS Statistics version 27.

\section{Results and conclusion}

Figure 1 shows the distribution of final marks for the self-efficacy scale. Graphically, it can be observed that students who selected 'completed confident' (i.e. scored 5 on the Likert scale) in their ability to achieve a grade that was above average performed well in the course, while students who scored 2 or 3 on the Likert scale did not necessarily perform better than their less confident peers.

A Kendall's tau-b $\left(\tau_{\mathrm{b}}\right)$ correlation was run to determine the relationship between self-efficacy and academic performance amongst the 401 participants. There was a moderate positive correlation between self-efficacy and final marks, which was statistically significant $\left(\tau_{\mathrm{b}}=.208, p=.000\right)$. 


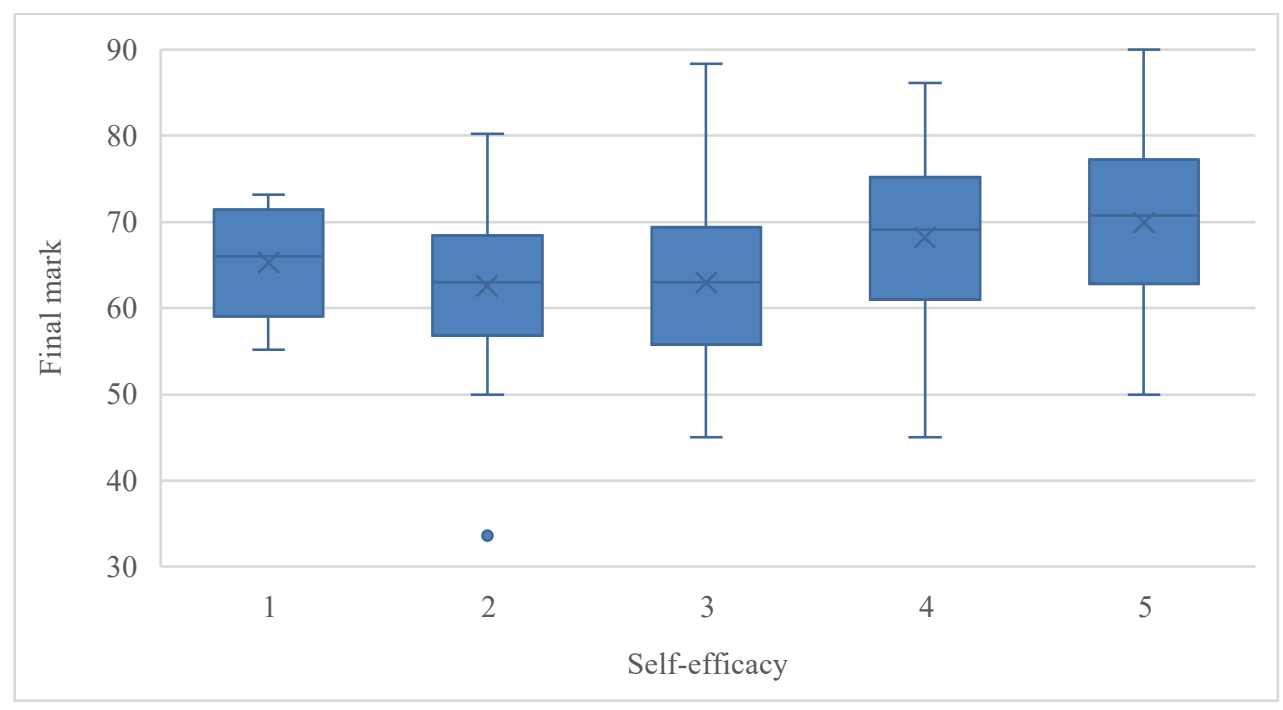

Figure 1. Final mark vs self-efficacy.

Therefore, given that self-efficacy is moderately positively correlated to academic performance, programmes should be developed to assist in fostering an environment where students are confident in their ability to perform well in a course.

It stands to reason that the next step should be to consider whether self-efficacy is significantly associated when controlling for factors identified in the literature. Further research could include a regression analysis, incorporating Grade 12 results, prior academic performance, age, gender, race and language. Another avenue would be to consider the impact of these variables in private tertiary education (Carpenter \& Kraus, 2020).

It is important to understand all factors affecting accounting students' academic success in tertiary education. Cognisance of these factors will assist universities to help students develop effective learning approaches, which should then improve their academic performance (Biggs, 1987). The research on the impact of self-efficacy in accounting students in South Africa is still in its infancy. However, investigating it in conjunction with other factors that may affect academic performance may help universities provide innovative support programmes and additional directed assistance (financial and otherwise) that will assist students' academic success.

\section{References}

Aboo, F. (2017). Non-academic factors contributing towards performance of postgraduate open distance learning accounting students. University of South Africa.

Beatson, N. J., Berg, D. A. G., \& Smith, J. K. (2020). The influence of self-efficacy beliefs and 
prior learning on performance. Accounting and Finance, 60(2), 1271-1294.

Biggs, J. B. (1987). Student approaches to learning and studying. Research Monograph. Australian Council for Educational Research. https://eric.ed.gov/?id=ED308201

Bokana, K. G., \& Tewari, D. D. (2014). Determinants of Student Success at a South African University: An Econometric Analysis. Anthropologist, 17(1), 259-277.

Byrne, M., Flood, B., \& Griffin, J. (2014). Measuring the Academic Self-Efficacy of First-year Accounting Students. Accounting Education, 23(5), 407-423.

Carpenter, R., \& Kraus, T. (2020). Potential determinants of students' academic success in private tertiary education in South Africa. 5th International Conference on Globalization, Entrepreneurship and Emerging Economies (ICGEEE), 69-78. https://doi.org/10.24052/BMR/V11NU02/ART-09

Carpenter, R., \& Kunaka, S. (2018). Gender-differentiated locus of control in a racially diverse accounting student body at a South African university. 30th Annual Conference of the Southern African Institute of Management Scientists (SAIMS), 16-29. ISBN: 978-0-79721729-4

Carpenter, R., \& Roos, L. (2020). Can We Afford It? The association between financial aid and time to completion in Accounting Higher Education in South Africa: A literature review. 9th International Conference on Business and Economic Development (ICBED), 222-232). https://doi.org/10.24052/BMR/V11NU01/ART-24

Christensen, T. E., Fogarty, T. J., \& Wallace, W. A. (2002). The Association between the Directional Accuracy of Self-Efficacy and Accounting Course Performance. Issues in Accounting Education, 17(1), 1-26. https://doi.org/10.2308/iace.2002.17.1.1

Coetzee, S. A., Janse van Rensburg, C., \& Schmulian, A. (2016). Differences in students' reading comprehension of international financial reporting standards: a South African case. Accounting Education, 25(4), 306-326.

Davidson, R. A. (2002). Relationship of study approach and exam performance. Journal of Accounting Education, 20(1), 29-44.

Gul, F. A., \& Fong, S. C. C. (1993). Predicting success for introductory accounting students: some further Hong Kong evidence. Accounting Education, 2(1), 33-42.

Jansen, J., \& de Villiers, C. (2016). Determinants of student performance in an accounting degree programme. South African Journal of Accounting Research, 30(1), 1-28.

Joynt, C., \& de Villiers, C. (2019). An Exploratory Study of the Impact of a Pre-University Course on the Academic Performance of Students in Introductory Accounting. https://ssrn.com/abstract=3331279

Kaburise, P. (2014). Why has Widening Access to Tertiary, in South Africa, Not Resulted in Success? Mediterranean Journal of Social Sciences, 5(20), 1309-1315.

Martirosyan, N. M., Hwang, E., \& Wanjohi, R. (2015). Impact of English Proficiency on Academic Performance of International Students. Journal of International Students, 5(1), $60-71$.

McKenzie, K., \& Schweitzer, R. (2001). Who Succeeds at University? Factors predicting academic performance in first year Australian university students. Higher Education Research \& Development, 20(1), 21-33.

Mooi, T. L. (2006). Self-efficacy and Student Performance in an Accounting Course. Journal 
of Financial Reporting and Accounting, 4(1), 129-146.

Myers, P. (2017). An analysis of how students construct knowledge in a course with a hierarchical knowledge structure. South African Journal of Accounting Research, 31(3), 193-211.

Nishimura, R., Wagner, J., \& Elliott, M. (2016). Alternative indicators for the risk of nonresponse bias: a simulation study. International Statistical Review, 84(1), 43-62.

Papageorgiou, E. (2017). Accounting students' profile versus academic performance: A fiveyear analysis. South African Journal of Higher Education, 31(3), 31-33.

Papageorgiou, E., \& Carpenter, R. (2019). Prior accounting knowledge of first-year students at two South African universities: Contributing factor to academic performance or not? South African Journal of Higher Education, 33(6), 249-264. https://doi.org/10.20853/336-3032.

Papageorgiou, K., \& Halabi, A. (2014). Factors contributing toward student performance in a distance education accounting degree. Meditari Accountancy Research, 22(2), 211-223.

Pullen, E., Toerien, F., \& Anthony, J. (2015). Student Endogenous Factors that Impact on Performance in Advanced Management Accounting: An Exploratory Study. In 2015 SAAA/IAAER Biennial Conference (pp. 604-621). Retrieved from http://www.saaa.org.za/ConferencePublications?Confid=7

Roos, S. (2009). Factors affecting Southern African students' success in CIMA examinations. Meditari Accountancy Research, 17(1), 48-67.

Sartorius, K., \& Sartorius, B. (2013). The comparative performance of chartered accountancy students in South Africa: The impact of historical legacies. Development Southern Africa, 30(3), 401-416.

Shamsoodien, S., \& Carpenter, R. (2020). Do Beliefs Matter in Accounting? Self-efficacy and Student Academic Performance in Accounting Higher Education in South Africa: A Literature Review. 2020 Southern African Accounting Association National Teaching and Learning and Regional Conference Proceedings in association with the Meditari Accountancy Research Conference, 479-495. ISBN: 978-0-620-90856-6

Steenkamp, G. (2014). How pre-admission characteristics affect the performance of CTA students at a South African university. Journal of Economic and Financial Sciences, 7(2), 283-298.

Swart, O., \& Becker, A. I. (2014). Matric results in mathematics and languages : A predictor of undergraduate and postgraduate success. Progressio, 36(1), 157-181.

Ungerer, M., Becker, A. I., Nieuwoudt, M. J., Swart, O., \& Wilcocks, J. S. (2013). The importance of the changing demographic profile on the success of postgraduate accounting students. South African Journal of Higher Education, 27(6), 1529-1550.

van Rooy, B., \& Coetzee-Van Rooy, S. (2015). The language issue and academic performance at a South African University. Southern African Linguistics and Applied Language Studies, 33(1), 31-46.

van Wyk, E. (2011). A Note: The SAICA Part I Qualifying Examinations: Factors that may influence candidates' success. South African Journal of Accounting Research, 25(1), 145174. 